\title{
LOCAL LABOR MARKET CONDITIONS AND RETIREMENT BEHAVIOR
}

\author{
Dan A. Black and Xiaoli Liang* \\ CRR WP 2005-08 \\ Released: May 2005 \\ Draft Submitted: April 2004
Center for Retirement Research at Boston College
550 Fulton Hall
140 Commonwealth Ave.
Chestnut Hill, MA 02467
Tel: 617-552-1762 Fax: 617-552-0191
http://www.bc.edu/crr

\begin{abstract}
*Dan Black is a professor of economics at Syracuse University and a senior research associate at the Center for Policy Research. Xiaoli Liang is a Dissertation Fellow in Economics at Syracuse University. The research reported herein was performed pursuant to a grant from the U.S. Social Security Administration (SSA) to the Center for Retirement Research at Boston College (CRR). The findings and conclusions are solely those of the authors and do not represent the views of SSA, any agency of the Federal Government, or Boston College.
\end{abstract}

(C) 2005, by Dan Black and Xiaoli Liang. All rights reserved. Short sections of text, not to exceed two paragraphs, may be quoted without explicit permission provided that full credit, including (C) notice, is given to the source. 


\section{About the Center for Retirement Research}

The Center for Retirement Research at Boston College, part of a consortium that includes a parallel centers at the University of Michigan and the National Bureau of Economic Research, was established in 1998 through a grant from the Social Security Administration. The goals of the Center are to promote research on retirement issues, to transmit new findings to the policy community and the public, to help train new scholars, and to broaden access to valuable data sources. Through these initiatives, the Center hopes to forge a strong link between the academic and policy communities around an issue of critical importance to the nation's future.

\section{Center for Retirement Research at Boston College \\ 550 Fulton Hall \\ 140 Commonwealth Ave. \\ Chestnut Hill, MA 02467 \\ phone: 617-552-1762 fax: 617-552-0191 \\ e-mail: crr@bc.edu \\ http://www.bc.edu/crr}

\section{Affiliated Institutions:}

American Enterprise Institute

The Brookings Institution

Center for Strategic and International Studies

Massachusetts Institute of Technology

Syracuse University

Urban Institute 


\begin{abstract}
In this paper, we explore the effect of local labor market conditions on the labor supply decisions of older workers. We use three different sources of variation: shocks to the US steel industry, shocks to Appalachian coal mining, and shocks to US manufacturing. While each experiment uses different methodology, the three tell a remarkably consistent story: the retirement decisions of Americans over the last thirty-five years have been affected by the performance of local labor markets. First, using variation induced by the decline in the US steel industry, we find that a 10 percent reduction in earnings resulting from the decline of the primary metals industry resulted in a 1.5 percent increase in the participation and expenditures of the Old Age program. Second, using variation in coal prices induced by oil shocks, we find that a 10 percent increase in earnings from the coal industry reduced participation about 0.9 percent and decreases expenditures about 1.2 percent. Finally, looking at variation induced by the concentration of manufacturing employment, we use micro data to examine the age and education levels of those who retired.
\end{abstract}




\section{Introduction}

As workers age, they must decide to what extent they will participate in the labor force in their later years. As with all potential workers, one factor that certainly enters this decision is the condition of the local labor market. While we know that prime-aged workers respond to changes in demand for their services, less is known about the responsiveness of older workers. This paper examines the effect of local demand for labor on the labor supply and Social Security participation decisions of older workers.

Male workers have experienced substantial changes in demand for labor over the past several decades. Many low-skilled men, who were employed in manufacturing during their prime working years, later experienced declining wages as that sector of the economy waned. Moreover, because manufacturing provided relatively generous pensions, workers who were displaced from manufacturing often had generous pension plans that afforded them the opportunity to retire. The existing literature (e.g., Hurd, 1997, and Lumsdaine and Mitchell, 1999) has documented the incentives that defined benefit plans provide for retirement, often at ages well before eligibility for Social Security.

In this paper, we explore the effect of local labor market conditions on the labor supply decisions of older workers. In particular, we wish to determine the extent to which the trends in labor force participation for older men can be explained by economic shocks that have changed the demand for older workers. While changes in the Social Security system are at least partially responsible for the decreases in labor force participation of older men, it is also probable that the erosion of male wages, particularly among low-skilled workers, played a role.

We use three different sources of variation. First, following Black, Daniel, and Sanders (2002) and Black, McKinnish, and Sanders (2003), we exploit the decline of the US primary metals industry - primarily the steel industry - and ask if counties that had a concentration of factories in the primary metals industry had higher take-up rates and higher expenditures in the 
Old Age components of OASDI expenditures when the industry declined sharply starting in 1981. Because the distribution of earnings in primary metals is very concentrated, we limit our analysis to eight states with the largest concentration of primary metals earnings: Alabama, California, Illinois, Indiana, Michigan, Ohio, New York, and Pennsylvania. Even within these states, there is much variation in the concentration in primary metals employment. Using this variation in concentration of the primary metals industry, we find that a 10 percent reduction in earnings resulting from the decline of the primary metals industry resulted in a 1.5 percent increase in the participation and expenditures of the Old Age program.

Again following Black, Daniel, and Sanders (2002) and Black, McKinnish, and Sanders (2003), we use the boom in the coal industry associated with the 1973 OPEC Oil Embargo and the subsequent collapse in the industry with the sharp decline in oil prices in the 1980 s to assess how the boom and bust in the coal industry affected participation and expenditures in the Old Age program. We find that a 10 percent increase in earnings from the coal industry reduced participation about 0.9 percent and decreases expenditures about 1.2 percent.

Finally, we examine the impact of the decline in US manufacturing on the labor force participation of older men. We exploit the geographic variation in the concentration of manufacturing and explore intercity variation in the concentration in manufacturing. Using a classic Wald (1940) estimator, we divide cities into thirds by their concentration of manufacturing employment in 1970. We ignore the middle third of the distribution and then compare the evolution of retirement behavior for cities with a high concentration of manufacturing, which we call industrial cities, relative to cities with a low concentration of manufacturing, or nonindustrial cities, using data from the US Census from 1970 to 2000 . We find that the labor force participation of older workers in cities with a high concentration of manufacturing employment as well as those with a low concentration of manufacturing declined about the same between 1970 and 1980 . 
Between 1980 and 1990 - a period of rapid decline in US manufacturing - the labor force participation of older workers in the industrial cities fell at a much faster rate than the corresponding labor force participation rate in nonindustrial cities. Indeed, the labor force participation rate of older workers fell four times as fast in the industrial cities as in the nonindustrial cities. Between 1990 and 2000, the decline in labor force participation was still larger in the industrial cities than in the nonindustrial cities.

The remainder of the paper proceeds as follows. In the next section, we describe our conceptual framework for thinking about the impact of the decline of manufacturing on retirement behavior. In section 3, we describe our data and estimation strategy, and in section 4 we provide our estimates. Finally, we offer some brief discussion in section 5 and concluding remarks in section 6 .

\section{Conceptual Framework}

In this section, we briefly outline the conceptual framework for our analysis. There are at least three reasons to expect that the changing industrial structure of the United States may affect the labor force participation of older Americans. At least since the work of Wilson (1987), and Wilson and Neckerman (1986), social scientists have realized that the decline in US manufacturing has affected the economic prospects of low-skilled Americans and the impact of the decline may manifest itself in unexpected ways. The manufacturing industry provided lowskilled workers with high-paying jobs, and these jobs often afforded workers generous pensions. If leisure is a normal good, the wealth associated with these jobs allowed these workers the opportunity to retire at a relatively early age.

Second, because of the well-documented decline in US manufacturing, workers found themselves suffering very substantial declines in their earnings capacity; for instance, Jacobson, LaLonde, and Sullivan (1993) estimate that workers in the Pennsylvanian steel mills who lost their jobs experienced a permanent 25 percent decline in their earnings capacity. (Chan and 
Stevens $(2001,2004)$ document that older workers who lost their jobs are likely to withdraw from the labor market.) For older workers at the end of their work lives, this reduction in earnings capacity represents a substantial reduction in the cost of their leisure, suggesting that the decline in US manufacturing may have encouraged early retirement for these workers. When firms seek to reduce employment, they often use incentive programs designed to encourage older workers to retire from the firm. We find that these types of layoffs are not necessary to encourage such early retirement.

Third, because of the concentration of manufacturing, the decline in manufacturing could have substantial impacts on local housing markets. For instance, with the rapid decline of the automobile industry in Flint, Michigan, housing prices declined nearly 27 percent in Flint from a high in the third quarter of 1981, according to the Fannie Mae/Freddie Mac Weighted Repeat Sales House Price Index. Nominal housing prices did not recover their 1981 level until the second quarter of 1987. As housing is the largest source of non-pension wealth for most Americans, the decline of the values of homes may represent a significant wealth shock. Coupled with the loss of earnings associated with displacements, the decline in housing prices may have represented a substantial reduction in the wealth of workers, which may induce them to delay their retirement decisions. Thus, the dramatic decline in US manufacturing is likely to have both price and wealth affects that could affect the retirement behavior of workers.

\section{Description of the Data}

For this paper, we use data from three sources: the Bureau of Economic Analysis' Regional Economic Information System (REIS), the 1970, 1980, 1990, and 2000 Public Use Micro Samples (PUMS) of the Census, and SSA data on Old Age and Disability Insurance that was entered into the computer by Keyoung Information, Limited, of Hong Kong. We use extracts from the IPUMS project; see King, Ruggles, and Sobe (2003) for a description of the data. The PUMS affords us a very large sample of workers, which allows us to look at variations 
in labor force participation rates of older workers across cities. The REIS data provides information on MSA-level and county-level national income accounts data and detailed information on the local economies.

\section{A. The Decline of the US Primary Metals Industry}

The US primary metals industry suffered a sharp decline in employment and earnings as increased foreign competition made US production of steel increasingly uncompetitive. Because the production of steel requires large quantities of ore and coal, access to water transportation was critical, and production was concentrated in the Great Lakes region and Alabama and California. These eight states have the largest fraction of employment in primary metals in 1970, accounting for nearly 69 percent of total primary metals employment in the United States.

In Figure 1, we depict the real earnings in the primary metals industry from 1969 to 2000, which we have deflated with the Consumer Price Index, and 1983 serves as the base year. Workers who were displaced by the collapse of the steel industry experienced huge earnings losses. Carrington and Zaman (1994) document that primary metals workers experienced nearly a 25 percent reduction in wages after displacement, and Jacobson, LaLonde, and Sullivan (1993) find that the earnings loss is over $\$ 10,000$ per year (in 1987 dollars) five years after displacement.

Because the steel industry is geographically concentrated, the collapse of steel manufacturing was not felt equally across all counties. In the 8 -state region in 1969, 60 percent of counties have less than 1 percent of total employment in primary metals, while 8 percent of counties have more than 10 percent of employment in primary metals. ${ }^{1}$ Those counties with little steel employment were left relatively untouched by the decline in steel manufacturing, while those with high concentrations were very hard hit by the decline. Because the decline in

\footnotetext{
${ }^{1}$ In the 1970 Public Use Micro Sample (PUMS) data, 79 percent of primary metals workers in our 8-state region were steelworkers.
} 
primary metals ends about 1991, we limit our analysis of the shock from 1970 to 1991 data. For more detail about the decline of the primary industry, see Black, McKinnish, and Sanders (2003).

To characterize the county's dependency on the primary metals industry, we calculated the fraction of men in the county employed in primary metals manufacturing in 1969 from the $4^{\text {th }}$ County Population File C from the 1970 Census.

\section{B. The Boom and Bust of the Coal Industry}

Our analysis of the coal economy focuses on the states of Kentucky, Ohio, Pennsylvania, and West Virginia. The Appalachian regions of these states have traditionally been poor and dependent on the coal economy. Figure 2 plots the real price of coal over time and the fraction of earnings in the 4-state region attributed to mining. Until 1969, the real price of coal was quite stable. Regulatory changes and the OPEC oil embargo generated massive increases in coal prices. These price increases generated a tremendous boom in the coal economy. The price of coal and coal earnings then stabilized for many years but fell during the 1980s. The bust occurred not only because of the drop in the prices of coal and oil, but also because new mines opened in the northern Rocky Mountains and new mining technologies reduced the demand for low-skilled miners. ${ }^{2}$

As with steel, these economic shocks were not felt equally in all counties in the four-state region. Figure 3 depicts the coal reserves of the counties in our four-state region. Some counties have substantial coal reserves and benefited from the boom in the coal industry and suffered from the bust. To calculate the county's dependence on the coal industry, we use the coal reserves measure that we plotted in Figure 3. More than half of the counties in this region, however, have virtually no coal and were not directly affected by the coal boom and bust. In areas with coal, however, the impact of the coal industry's boom and bust was extremely large. For instance, Pike County, Kentucky, has one of the largest reserves of coal in the region, with

\footnotetext{
${ }^{2}$ See Merrell (1999) for an excellent description of the coal industry in the 1980 s.
} 
over 6.8 billion tons of known reserves. In 1969, Pike County had a per capita income that is only 53 percent of US per capita income. During the coal boom, this figure rises dramatically to 90 percent in 1980, and then plummets as the coal industry declines. By 1988, Pike County's per capita income is back down to 63 percent of national per capita income. To keep our analysis compatible with Black, Daniel, and Sanders (2002) and Black, McKinnish, and Sanders (2003), we limit our analysis from 1970 to 1993.

\section{The Decline of US Manufacturing}

In Figure 4, we plot the fraction of earnings in manufacturing from 1969 to 2000 for the US as a whole. While the decline is throughout the time period, the decade of the $1980 \mathrm{~s}$ is particularly strong. For instance, between 1971 and 1979, the fraction of earnings in manufacturing in the US declined from about 25.3 percent to 25.0 percent. By 1990, however, the fraction employed in manufacturing fell to only 19.0 percent and continued to fall to just 16.5 by 2000 .

The national analysis, however, hides an important degree of heterogeneity among US cities. In Panel A of Table 1, we provide various percentiles of the distribution of the employment in manufacturing in 1970 for the 50 largest cities in the United States. The magnitude of the interquartile range is over 17 percent; the standard deviation is over 10 percentage points. In Panel B of Table 1, we list the 17 most industrialized cities and the 17 least industrialized in 1970. This heterogeneity will form the basis of our identification strategy. We divide the cities into three groups: the nonindustrial cities that are in the bottom third of the distribution (17 cities), the industrial cities that are in the highest third of the distribution (17 cities), and the middle of the distribution (16 cities).

To keep our samples reasonably large within cities, we limit our sample to the fifty largest cities in the United States. We also limit our sample to white men between the ages of 56 and 64. 
In Table 2, we present a couple of basic summary statistics for the sample. The education of this group of workers has increased remarkably over the period. In 1970, only about 11.4 percent of the workers had a four-year college degree or more, but by 2000 this number had grown to 35.3 percent. There is also a remarkable increase in the percentage of these workers who were no longer in the labor force, which we will casually refer to as "retired." In 1970, 82.6 percent of this group was in the labor market, but by 2000 only 69.3 percent remained in the labor market. Moreover, given that labor force participation is highly correlated with education in these age groups, the increase in educational attainment of this population mitigated the decline in labor force participation. ${ }^{3}$

\section{Estimation}

\section{A. Primary Metals Industry}

For the steel states, the instrument is the fraction of men in the county employed in primary metals manufacturing in 1969 and the interaction of that variable with the fraction of total earnings in the United States in that year attributable to the primary metals industry. The employment concentration measure, calculated from the $4^{\text {th }}$ County Population File C from the 1970 Census, provides a measure of each county's vulnerability to the decline of steel. The earning share, calculated annually from BEA data, measures changes in demand for steel at the national level, arising from factors such as foreign competition or changes in production technology that should be exogenous to the individual county. Thus, for our instrument, we interact a measure of a county's dependence on steel with a measure of aggregate demand for domestic steel.

Following Black, Daniel, and Sanders (2002) and Black, McKinnish, and Sanders (2003), we specify a log-difference equation:

$$
\Delta y_{i t}=\text { year' }_{\mathbf{t}}^{\prime} \boldsymbol{\alpha}+\beta \Delta \text { earnings }_{i t}+\varepsilon_{i t},
$$

\footnotetext{
${ }^{3}$ Not too surprisingly, the age of these workers varied little, with the mean ranging from 59.6 to 60.0 years.
} 
where $\Delta y_{i t}$ is the logarithmic difference in the ith county's Old Age expenditures (or Old Age recipients) at time $t$, year' is a vector of time dummies, $\Delta e a r n i n g s_{i t}$ is the ith county's logarithmic difference in earnings at time $t, \varepsilon_{i t}$ is the regression error, and $(\boldsymbol{\alpha}, \beta)$ are parameters to be estimated.

Because we estimate the equation in a difference form, any time-invariant fixed effects are removed. But the estimation of the difference equation is not without its costs. Because the difference equation differences out permanent components of earnings, the variation in $\Delta e a r n i n g s_{i t}$ that is used to identify the parameter $\beta$ in OLS estimation is comprised primarily of relatively short-term fluctuations in $\Delta$ earnings $_{i t}$. Unfortunately, one suspects that short-term fluctuations in earnings have little impact on retirement decisions, which creates a potentially severe measurement error problem.

A heuristic argument will help explain the problem. Let $\Delta$ earnings $s_{i t}$ be decomposed into a permanent part, $\pi_{i t}$, and a transitory part, $\tau_{i t}$ so that $\Delta$ earnings $s_{i t}=\pi_{i t}+\tau_{i t}$ and where we assume that $\operatorname{cov}\left(\pi_{i t}, \tau_{i t}\right)=0$. Further, suppose we wish to interpret $\beta$ as the impact of permanent earnings changes on the retirement decisions. Because the transitory earnings fluctuations $\left(\tau_{i t}\right)$ are uncorrelated with Old Age expenditures, the probability limit of the OLS estimate ( $b^{\text {OLS }}$ )of $\beta$ is simply:

$$
\operatorname{plim}\left(b^{O L S}\right)=\beta \frac{\tilde{\sigma}_{\pi}^{2}}{\tilde{\sigma}_{\pi}^{2}+\tilde{\sigma}_{\tau}^{2}}
$$

where $\tilde{\sigma}_{\pi}^{2}$ is the variance of $\pi_{i t}$ once the time fixed-effects are removed and $\tilde{\sigma}_{\tau}^{2}$ is the variance of $\tau_{i t}$ once the time fixed-effects are removed. If the variance of $\tau_{i t}$ is large relative to the variance of $\pi_{i t}$, the OLS estimate may be very attenuated. 
To focus on the impact of permanent changes in earnings on Old Age participation, we instrument for the earnings changes using the equation:

$$
\Delta \operatorname{earnings}_{i t}=\text { year. }_{\mathbf{t}}^{\prime} \mathbf{a}_{1}+a_{2} z_{i t}+e_{i t} \text {, }
$$

where $z_{i t}$ is our instrument formed by the interaction of 1969 employment in primary metals and the national fraction of earnings in the primary metals industry each year, $e_{i t}$ is the regression error, and $\left(\mathbf{a}_{1}, a_{2}\right)$ are parameters to be estimated. We then use the predicted value of earnings from equation (3) to estimate:

$$
\Delta y_{i t}=\text { year }_{\mathbf{t}}^{\prime} \boldsymbol{\alpha}+\beta \Delta \text { earnings }_{i t}+\hat{\varepsilon}_{i t}
$$

where $\Delta$ earnings $s_{i t}$ is the predicted earnings from equation (3).

The use of predicted earnings substantially reduced the magnitude of the variation in earnings. For instance, the $\mathrm{R}^{2}$ in the first-stage equation (equation 3 ) is only about 0.33 , and much of that explanatory power is from the year dummies with only about 0.15 percent of the variation explained by the instrument. The instrument, however, is quite significant with a marginal F-statistic of over 26; see Table 3. The impact of these persistent changes earnings is statistically significant and economically meaningful. A 10 percent decline in the earnings within a county results in a 1.5 percentage point increase in Old Age expenditures and Old Age recipients.

\section{B. The Boom and Bust in the Coal Industry}

Our analysis of the coal shocks has a feature not available in the analysis of the steel shocks. Unlike the decline of steel, we have access to a measure of industry concentration that is particularly easy to defend as exogenous: the amount of coal reserves in the county. We use the price of coal as our measure of changes in demand for coal. Thus, our instrument is the change in the value of coal in the county as measured by the logarithm of the amount of coal reserves multiplied by the logarithmic difference of the real price of coal. As Black, McKinnish, and 
Sanders (2003) document, changes in earnings lag behind changes in the price of coal, as it can take time for a mine to open in response to a price change. Therefore, we include a lag of the value of coal reserves as an instrument as well.

Our econometric specification is similar to the one we used for our analysis of the primary metals industry. In particular, we estimate the impact of earnings changes on Old Age expenditures and recipients using the equation (1):

$$
\Delta y_{i t}=\text { year' }_{\mathbf{t}}^{\prime} \boldsymbol{\alpha}+\beta \Delta \text { earnings }_{i t}+\varepsilon_{i t} .
$$

Again, while the difference equation sweeps out time invariant fixed effects that might confound our estimates, the difference equation approach makes the variation earnings used for identification of $\beta$ in OLS estimation excessively dependent on the short-term fluctuation in earnings that we think may not affect the retirement decision of older workers. Concern about the reliance short-term fluctuations in earnings, leads us to estimate equation (1') instead:

$$
\Delta y_{i t}=\text { year }_{\mathbf{t}}^{\prime} \boldsymbol{\alpha}+\beta \Delta \text { earnings }_{i t}+\hat{\varepsilon}_{i t},
$$

using our value of coal reserves instruments.

We present the results in Table 4. The marginal F-statistics on the instruments is considerably larger, 48 rather than the 26 from the steel industry. Interestingly, most of the strength of the instrument appears to be on the lagged value of the instrument. While the firststage regression explains over 30 percent of the variation in the change in earnings, the time dummies account for about 29 percent of the variation and the instruments about 1.5 percent of the variation, which is larger by an order of magnitude than the explanatory of the instrument for the steel analysis.

Nevertheless, the results are reasonably consistent with the steel analysis. A 10 percent increase in the earnings associated with the coal boom reduces Old Age expenditures about 1.2 
percent and Old Age recipients about 0.9 percent. Both estimates are highly statistically significant and, given the magnitude of the program, economically significant as well.

Of course, one weakness in both the steel and coal analysis is our reliance on aggregate data. We cannot identify who is responding to the shocks to the local economy. In the next section, we address that weakness by using data from the 1970 to 2000 Public Use Micro Samples (PUMS) of the Decennial Censuses.

\section{The Decline in Manufacturing}

While the analysis using county-level data is suggestive, the analysis remains ultimately incomplete because it cannot tell us about the age structure of those who do not participate in the labor market as a result of a shock to the local economy. If a shock reduced the labor force participation of those, say, aged 55 to 58, the full impact of the local shock will not be felt for another seven years when the 55 year olds turn 62 . Nor can it provide any insight into the education level of the workers who are retiring.

In this section, we use data from the 1970 to 2000 PUMS to look at these issues. In many ways, however, the PUMS is less than ideal. It provides us with observations once every 10 years, and because it is a cross section, it does not allow us to follow workers over time. Moreover, there is only limited migration in PUMS so it is not generally possible to identify a worker who worked his whole life in the steel mills of Pittsburgh and retired to Fort Meyers.

With these caveats in mind, we now turn to the PUMS analysis. Because we want to make as few parametric assumptions as possible, we limit our analysis to white, non-Hispanic men between the ages of 56 and 64. While the PUMS does afford large data sets, the relatively small number of African-Americans (about 10 percent of the population), and their geographic 
concentration made it too difficult to include them in the analysis. These problems are even more severe for Hispanic, Asian, and Native American men. ${ }^{4}$

We exclude women for two reasons. First, there is a growing literature on the joint retirement decision of men and women (e.g,, Blau, 1998) and we did not wish to have to model this joint retirement decision in our nonparametric framework. Second, women tend to be younger and have lower earnings than their spouses, particularly in the early years of our sample. Thus, women tend to be the secondary earners in their households for much of this time period. Clearly, the extension of this work to women and minority men would represent an important addition, but is outside the scope of this project.

In general, we wish to estimate an equation of the form:

$$
y_{i t c}=g\left(x_{i t c}, L_{t c}\right)+\varepsilon_{i t c}
$$

where $y_{i t c}$ is the labor force participation decision of the ith worker, in the cth city, at tth year, $x_{i t c}$ is a vector of covariates, $L_{t c}$ is a measure of local labor market conditions, and $\varepsilon_{i t c}$ is the regression error, which we assume to be independent of all other covariates. The function $g(\square)$ is an unknown function.

When the dimensionality of $x_{i t c}$ is large relative to the number of observations, this type of model requires the use of kernel methods for estimation. Because we limit our sample to white, non-Hispanic men, we are also able to limit our covariates to age and education. With this relatively small number of covariates, we can approximate $g(\square)$ with a fixed effect for the workers age, education categories, and city of residence. The rate of retirement in the city could be modeled as:

$$
y_{i j k t}=\alpha_{i j k}+z_{c t}^{\prime} \beta_{c t}+\varepsilon_{i j k t}
$$

\footnotetext{
${ }^{4}$ The use of the entire long-form data would greatly improve the coverage of these groups because the long-form data is a one-insix, rather than a one-in-twenty sample of Americans. The use of these data, however, is possible only in a secure Census data Center.
} 
where $y_{i j k t}$ is the rate of labor force participation in the ith city, in the $j$ th educational category, in the $k t h$ age category, and in the th year. In our analysis, we use four education categories (less than a high school degree, high school degree, some college, and bachelor's degree or more) and three age categories ( 56 to 58,59 to 61 , and 62 to 64 ). To keep the age and education from having independent effects on the retirement rates, we weight the data so that each city, in each year, has the same joint distribution of age and education categories as the US in the 1990 Census. This has the impact of making the age and education categories orthogonal to the retirement variable, and hence, they will not affect any of the other parameter estimates. The variable $z_{c t}^{\prime}$ is a vector of dummy variables for the worker being in the $c t h$ type of city (industrial city, medium industrial city, or nonindustrial city) and in the $t$ th year.

Rather than estimate equation (4) directly, we difference the data dependent variable to remove the city fixed effects $\left(\alpha_{i j t}\right)$ and estimate the model:

$$
\Delta y_{i j k t}=z_{c t}^{\prime} \beta_{c t}+u_{i j k t}
$$

where $\Delta y_{i j k t}$ is the change in the retirement rate and $u_{i j k t}$ is the differenced error term. This estimation approach implicitly conditions on our age, education categories, and city of residence.

We wish to compare the retirement behavior of older workers who live in industrial cities to those living in nonindustrial cities. As such, our strategy is similar to that which Wald (1940) used in his classic paper. In the paper, Wald recommends "fitting the regression line" by connecting the mean value of the variable from the bottom half of the distribution and the mean value from the top half of the distribution. Theil (1971) reports that subsequent research has shown more accurate fits are obtained by leaving out the middle of the distribution. The division of the cities into thirds nicely separates the cities. Among our nonindustrial cities, only 12 percent of the employment is in manufacturing, but over 34 percent of employment in our industrial cities is in manufacturing. The highest concentration of our nonindustrial cities is 
just 18 percent in manufacturing (Houston) while the smallest concentration in our industrial cities is 28 percent in manufacturing (Los Angeles).

In Table 5, we report estimates for equation (5) for the complete sample. Interestingly, between 1970 and 1980, the rate of retirement actually increased faster in our nonindustrial cities than our industrial cities, although the difference is not statistically significant at conventional levels. Between 1980 and 1990, however, the growth in the retirement rate is over four times higher in our industrial cities than in our nonindustrial cities. Thus, the decline seems to have largely abated in our nonindustrial cities by 1980, but continued through the 1980s in our industrial cities. Finally, between 1990 and 2000, the rate of retirement - although slowed increased twice as fast in our industrial cities as in our nonindustrial cities. ${ }^{5}$

These finding are consistent with the notion that deindustrialization was responsible for much of the decline in labor force participation of older workers during the 1980s and 1990s. For workers who lived in heavily industrialized cities, the labor force participation rate declined by 11.7 percent during the 1980s and 1990s, but for workers who lived in our nonindustrial cities, the decline was only about 3.8 percent. Because we have standardized for the distribution of education and age, these results do not reflect changes in the intercity distribution of education or ages. In addition, our use of the differenced equation removes any age-education-city fixed effects from the data. Thus, no time-invariant differences between the cities would seem to account for this shift.

While equation (5) is a reasonably flexible functional form, it does constrain the impact of the city's industrial base to be the same across education and age categories. In Table 6, we relax that assumption and estimate the model separately for each of our three age categories. Two results are of particular interest. First, among the two youngest age categories, the change in retirement rates during the 1970 s is substantially higher in the nonindustrial cities than in the

\footnotetext{
${ }^{5}$ As one might expect, our cities in the middle of the fraction of employment in manufacturing have growth rates in the middle of the two extremes; results available upon request.
} 
industrial cities, although the results for those 56 to 58 are imprecisely estimated. Second, while the results are completely in agreement with those from Table 3, the youngest two age categories account for the largest portion of the slowdown in retirement behavior and the largest portion of the difference in retirement behavior between 1980 and 1990.

In Table 7, we estimate equation (5) separately for each of our four educational categories. The results from Table 5 are remarkably consistent with the aggregate results from Table 5. For each educational category, the point estimates indicate that the growth in retirement between 1970 and 1980 was higher in nonindustrial cities than our industrial cities. Between 1980 and 1990, the rate of retirement grew more in our industrial cities than our nonindustrial cities, and the difference is statistically significant for each group. Finally, the point estimates for each educational category indicate that the growth in retirement rates between 1990 and 2000 was larger in our industrial cities than in our nonindustrial cities, although the difference is only statistically significant for the two highest educational categories.

Thus, the increased growth in retirement rates in traditionally industrialized cities appears throughout the age and education distributions of older workers. As these labor markets were subject to large negative shocks during the last twenty years, one naturally might ask if their impact differential rate growth in retirement rates represented increases in the demand for leisure during these years of life or simply represented declines in economic opportunities.

\section{Discussion}

\section{A. Threats to Internal and External Validity}

Evidence from the coal boom and bust, the collapse of the US steel industry, and the general decline in manufacturing demonstrates that the retirement decision is sensitive to the prevailing economic conditions. While, as a whole, we believe that the evidence is reasonably compelling, we want to discuss briefly threats to the internal and external validity of our findings. 
A major threat to the external validity of our findings is that coal, steel, and manufacturing workers are very different than the typical American worker. Workers in these industries tended to be relatively low skilled (as measured by their levels of schooling), geographically concentrated (especially coal and steel workers), and had excellent pension benefits. This latter difference, of course, is likely to be of first-order importance. Unfortunately, without detailed information about the pension benefits for which workers are eligible (and many of these shocks occurred over thirty years ago), this appears to be an insurmountable shortcoming.

Second, the internal validity of our estimates for the coal and steel industry using the county-level data is threatened by our PUMS evidence. In our analysis of the decline of US manufacturing, we found that there was a substantial increase in nonparticipation of not only those workers who are eligible for Old Age benefits, but also those workers who are too young for those benefits. To the extent that those workers who retire earlier than 62 simply remain out of the labor market and wait to become eligible for their Old Age benefits, our simple difference model will tend to understate the cumulative impact because our specification of the difference equation will not measure the cumulative run up in the benefits.

Third, we face a common problem whenever we attempt to assess the impact of local labor markets on economic decisions: migration. The migration problem, however, may be particularly severe when dealing with retirement. Because many retired workers migrate to other locations, there is no guarantee that a worker will take his benefits in the location where he worked for most of his life. If the propensity to migrate was unaffected by shocks to the labor market, this would not cause too great of a concern. One might expect, however, that a shock to local labor markets - particularly of the magnitude of many of the shocks we examine - could have substantial effects in housing markets as well. Because housing represents a substantial portion of the savings of Americans, the shock to the housing market could substantially reduce 
the mobility of retired workers. Thus, in an extreme case, little if any of the increased rates of labor force nonparticipation and increases in benefits are the result of actual increases in withdrawals from the labor market, but rather merely represent a reduction in the out migration of retired workers.

Unfortunately, little can be done about the migration problem with traditional data sets. While there are data sets that track older Americans over time and across different cities, these longitudinal data sets are quite expensive to gather. As a result, they are relatively small data sets when it comes to attempting to identify the impact of worker dislocation on retirement and mobility decisions. ${ }^{6}$

Finally, the housing market offers one more threat to our external validity. While it may be tempting to apply our estimates to all displaced workers, this would clearly be inappropriate because we strongly suspect - much like Flint, Michigan - communities that suffered these large economic shocks experience very long-term declines in housing prices. These changes in house prices represent substantial wealth shocks to dislocated workers. Because workers not involved in mass layoffs will not have these types of shocks to their housing markets, extrapolation of our results to these workers is clearly inappropriate.

\section{B. Why Should We Care?}

Given the age of the shocks that we analyze, a reader may be tempted to say, "This is modestly interesting economic history, but it has no relevance to the debate on Social Security today." We think this would be in error for two reasons. First, while no one can say for sure, it seems quite likely that the United States will be buffeted by shocks similar to the coal and steel industry in the future. Having some basic notion about the magnitudes of the labor supply and retirement effects of such a shock would seem essential for informed policy.

\footnotetext{
${ }^{6}$ In principle, this problem could be addressed using SSA records of employment and benefits.
} 
Second, current SSA estimates of retirement behavior rely on the analysis of historical

trends in retirement behavior. According to the 2004 OASDI Trustee's Report:

"The ultimate projected labor force participation rates are not basic assumptions. They are derived from a historicall

y-based structural relationship using demographic and economic assumptions specific to each alternative. Little variation in the structural relationship is assumed, and participation rates are not highly sensitive to most of the demographic and economic assumptions. Thus, the ultimate projected labor force participation rates vary modestly into the future, and across alternatives.

Historically, labor force participation rates have been influenced substantially by trends in demographics and pensions. Between the mid-1960s and the mid-1980s, labor force participation rates at ages 50 and over declined for males and were fairly stable for females. These overall declines were likely due in large part to the large numbers of workers entering the labor force from the baby-boom generation, and from the female population in general, during this period. This large supply of labor allowed employers to offer early-retirement options that were attractive. Between the mid-1980s and about 1995, these rates roughly stabilized for males and increased for females. Since 1995, however, participation rates at ages 50 and over have generally risen significantly, reflecting a decrease in early-out options and relatively strong economic growth."

While the projections clearly focus on the pension status of Americans, they ignore the large changes that resulted from shocks to the US economy during the time period. While the aggregate data rates of labor force participation may well have been stable, our results demonstrate that there was substantial heterogeneity within regions of the US. Simply relying on aggregate may cause us to miss important changes in the underlying retirement behavior of Americans.

\section{Concluding Remarks}

In this paper, we explore the effect of local labor market conditions on the labor supply decisions of older workers. We use three different sources of variation: shocks to the US steel industry, shocks to Appalachian coal mining, and shocks to US manufacturing. While each experiment uses different methodology, the three tell a remarkably consistent story: the retirement decisions of Americans over the last thirty-five years have been affected by the performance of local labor markets. 
Following Black, Daniel, and Sanders (2002) and Black, McKinnish, and Sanders (2003), we exploit the decline of the US primary metals industry - primarily the steel industry - and ask if counties that had a concentration of factories in the primary metals industry had higher take-up rates and higher expenditures in the Old Age components of OASDI expenditures when the industry declined sharply starting in 1981. Because steel production benefits from good access to water transportation, proximity to ore fields, and proximity to coal mines, the distribution of employment in the US steel industry is quite concentrated. Using this variation in concentration of the primary metals industry, we find that a 10 percent reduction in earnings resulting from the decline of the primary metals industry resulted in a 1.5 percent increase in the participation and expenditures of the Old Age program.

Our second experiment again follows Black, Daniel, and Sanders (2002) and Black, McKinnish, and Sanders (2003). We use the boom in the coal industry associated with the 1973 OPEC Oil Embargo and the subsequent collapse in the industry with the sharp decline in oil prices in the 1980s to assess how the boom and bust in the coal industry affected participation and expenditures in the Old Age program. Because coal can only be mined in locations that have endowments of coal, the distribution of coal mining employment is again quite concentrated. We find that a 10 percent increase in earnings from the coal industry reduced participation about 0.9 percent and decreases expenditures about 1.2 percent.

Finally, we examine the impact of the decline in US manufacturing on the labor force participation of older men. Surprisingly, we find a great deal of heterogeneity in the concentration of employment in manufacturing. Exploiting this variation, we find that the labor force participation of older workers in cities with a high concentration of manufacturing employment, as well as those with a low concentration of manufacturing, declined about the same between 1970 and 1980 . 
Between 1980 and 1990 - a period of rapid decline of US manufacturing - the labor force participation of older workers in the industrial cities fell at a much faster rate than the corresponding labor force participation rate in nonindustrial cities. Indeed, the labor force participation rate of older workers fell four times as fast in the industrial cities as in the nonindustrial cities. Between 1990 and 2000, the decline in the labor force participation was still larger in the industrial cities than in the nonindustrial cities.

Surprisingly, when we use the micro data and examine the education levels of workers, we find that the earlier retirement induced by deindustrialization was not concentrated among low-skilled workers. Indeed, the increase in the retirement rate induced by deindustrialization seems to be at least as high among workers with some college and at least a four-year college degree as for less skilled workers. 


\section{Table 1: Distribution of the Concentration of Fraction of Employment in Manufacturing in 1970}

Panel A:

$\begin{array}{lc}\text { Percentile } & \begin{array}{c}\text { Fraction of employment } \\ \text { in manufacturing }\end{array} \\ 10^{\text {th }} \text { percentile } & 0.097 \\ 25^{\text {th }} \text { percentile } & 0.142 \\ 50^{\text {th }} \text { percentile } & 0.232 \\ 75^{\text {th }} \text { percentile } & 0.313 \\ 90^{\text {th }} \text { percentile } & 0.364 \\ \text { Mean } & 0.231 \\ \text { Standard deviation } & 0.101\end{array}$

Panel B:

\begin{tabular}{lc||lc}
$\begin{array}{l}\text { 17 most } \\
\text { industrialized cities }\end{array}$ & $\begin{array}{c}\text { Fraction of } \\
\text { employment in } \\
\text { manufacturing }\end{array}$ & 17 least \\
industrialized cities & $\begin{array}{c}\text { Fraction of } \\
\text { employment in } \\
\text { manufacturing }\end{array}$ \\
Los Angeles & 0.276 & Las Vegas & 0.039 \\
Boston & 0.288 & Washington, DC & 0.046 \\
St. Louis & 0.292 & Honolulu & 0.061 \\
Philadelphia & 0.298 & Sacramento & 0.081 \\
Indianapolis & 0.313 & Austin & 0.093 \\
Pittsburgh & 0.316 & San Antonio & 0.102 \\
Chicago & 0.318 & Norfolk & 0.118 \\
Cincinnati & 0.319 & San Diego & 0.121 \\
Louisville & 0.334 & Oklahoma City & 0.130 \\
Buffalo & 0.346 & Orlando & 0.134 \\
Milwaukee & 0.357 & Miami & 0.136 \\
Cleveland & 0.357 & Salt Lake City & 0.136 \\
Detroit & 0.371 & New Orleans & 0.142 \\
Dayton & 0.382 & West Palm Beach & 0.150 \\
Charlotte & 0.386 & Tampa & 0.160 \\
Rochester & 0.400 & Denver & 0.161 \\
Greensboro & 0.454 & Houston & 0.180
\end{tabular}

Source: Authors' calculation, BEA's REIS data. The sample is the largest 50 cities in the US in 1990. 
Table 2: Summary Statistics for White Males Aged 56 to 64 Residing in 50 Largest Cities, 1970 to 2000 Census

$\begin{array}{lcccc}\text { Census year } & \begin{array}{c}\text { Less than high } \\ \text { school degree }\end{array} & \begin{array}{c}\text { High school } \\ \text { degree }\end{array} & \text { Some college } & \begin{array}{c}\text { Bachelor's } \\ \text { degree or more }\end{array} \\ 1970 & 56.03 \% & 21.63 \% & 10.95 \% & 11.39 \% \\ 1980 & 34.15 & 31.71 & 15.46 & 18.68 \\ 1990 & 23.57 & 26.50 & 21.59 & 28.33 \\ 2000 & 13.05 & 25.49 & 26.14 & 35.32\end{array}$

$\begin{array}{lccc}\text { Census year } & \text { In labor force } & \text { Not in labor force } & \text { observations } \\ 1970 & 82.58 \% & 17.42 \% & 27,546 \\ 1980 & 73.81 & 26.19 & 152,602 \\ 1990 & 68.99 & 31.01 & 124,447 \\ 2000 & 69.26 & 30.74 & 137,143\end{array}$

Notes: Authors' calculations, 1970 to 2000 PUMS. The sample is the largest 50 cities in the US in 1990. 


\section{Table 3: Impact of Earnings Changes on Old Age Payments and Recipients, Steel States 1970 to 1991}

$\begin{array}{cccc}\text { First-stage: } & \begin{array}{c}\text { Difference in } \\ \text { Difference in } \\ \text { logarithm of OA } \\ \text { parithm of } \\ \text { earnings }\end{array} & \begin{array}{c}\text { First-stage: } \\ \text { Difference in } \\ \text { logarithm of } \\ \text { earnings }\end{array} & \begin{array}{c}\text { Difference in the } \\ \text { logarithm of OA } \\ \text { recipients }\end{array} \\ & & & \end{array}$

Year dummies

Yes

Yes

Yes

Yes

Instrument

0.814

$(0.1590)$

0.814

$(0.1590)$

Change in earnings

-0.151
--
$(0.0591)$

$---$

11,755

11,755

11,759

$(0.0573)$

$\mathrm{N}$

26

26

instruments

Notes: Authors' calculation, SSA recipient and payment data, and REIS data. Clustered standard errors are report in the parentheses, where the clustering is with respect to county. There are 619 counties in the eight-state region. The eight states are Alabama, California, Illinois, Indiana, Michigan, Ohio, New York, and Pennsylvania 


\section{Table 4: Impact of Earnings Changes on Old Age Payments and Recipients, Coal States 1970 to 1993}

\begin{tabular}{|c|c|c|c|}
\hline First-stage: & Difference in & First-stage: & Difference in the \\
\hline Difference in & logarithm of OA & Difference in & logarithm of OA \\
\hline $\begin{array}{l}\text { logarithm of } \\
\text { earnings }\end{array}$ & payments & $\begin{array}{c}\text { logarithm of } \\
\text { earnings }\end{array}$ & recipients \\
\hline
\end{tabular}

\begin{tabular}{|c|c|c|c|c|}
\hline Year dummies & Yes & Yes & Yes & Yes \\
\hline Instrument & $\begin{array}{c}0.005 \\
(0.0028)\end{array}$ & --- & $\begin{array}{c}0.005 \\
(0.0028)\end{array}$ & --- \\
\hline Lagged instrument & $\begin{array}{c}0.026 \\
(0.0025)\end{array}$ & --- & $\begin{array}{c}0.026 \\
(0.0025)\end{array}$ & --- \\
\hline Change in earnings & --- & $\begin{array}{c}-0.121 \\
(0.0317)\end{array}$ & -- & $\begin{array}{c}-0.087 \\
(0.0237)\end{array}$ \\
\hline $\mathrm{N}$ & 6,928 & 6,928 & 6,928 & 6,928 \\
\hline $\begin{array}{l}\text { F-statistic on } \\
\text { instruments }\end{array}$ & 48 & --- & 48 & --- \\
\hline
\end{tabular}




\section{Table 5: Wald Estimates of the Impact of Deindustrialization on Retirement of White, Male Workers Aged 56 to 64}

\section{Change in non- participation rates}

1970 to 1980

1980 to 1990

1990 to 2000

\section{Nonindustrial Cities}

0.111

0.018

0.020
Industrial cities

0.084

0.076

0.041
Difference

$-0.026$

(0.0164)

[0.113]

0.058

$(0.0155)$

[0.000]

0.021

$(0.0090)$

[0.027]

Notes: Authors' calculations, 1970 to 2000 PUMS and BEA's REIS data. The sample is the largest 50 cities in the US in 1990. Data are weighted to provide a common age and education distribution across all cities. Cities are characterized as nonindustrial if their fraction of manufacturing employment to total employment is in the bottom third of the distribution for the fifty cities. Cities are characterized as industrial if their fraction of manufacturing employment to total employment is in the top third of the distribution for the fifty cities. Clustered standard errors are reported in parentheses and p-values are reported in brackets. 
Table 6: The Impact of Deindustrialization on Retirement of White, Male Workers by Age Categories

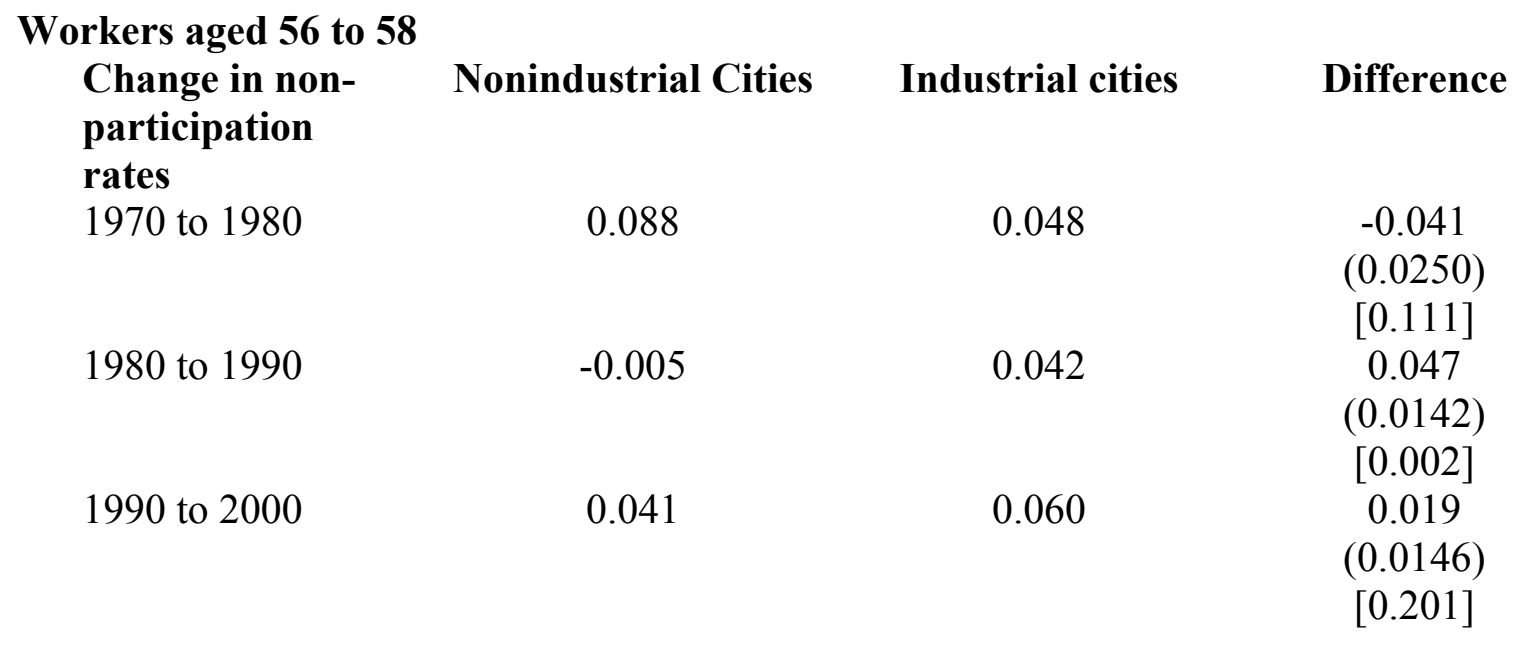

Workers aged 59 to 61

Change in nonparticipation rates

1970 to 1980

Nonindustrial Cities Industrial cities

Difference

0.116

0.052

$-0.064$

$(0.0208)$

[0.004]

1980 to 1990

$-0.004$

0.077

0.082

(0.0183)

[0.000]

1990 to 2000

0.032

0.046

0.014

(0.0105)

[0.183]
Workers aged 62 to 64
Change in non- participation rates 1970 to 1980
Nonindustrial Cities Industrial cities Difference
0.128
0.154
0.026
$(0.0265)$
[0.332]
1980 to 1990
0.061
0.108
0.047
$(0.0213)$
[0.033]
1990 to 2000
$-0.012$
0.017
0.029
$(0.0143)$
[0.052]

Notes: Authors' calculations, 1970 to 2000 PUMS and BEA's REIS data. For additional notes, see Table 5. 


\section{Table 7: The Impact of Deindustrialization on Retirement of White, Male Workers by Education Categories}

Workers with less than high school degree:

\begin{tabular}{|c|c|c|c|}
\hline $\begin{array}{l}\text { Change in non-participation } \\
\text { rates }\end{array}$ & Nonindustrial Cities & Industrial cities & Difference \\
\hline 1970 to 1980 & 0.150 & 0.143 & $\begin{array}{c}-0.007 \\
(0.0171) \\
{[0.672]}\end{array}$ \\
\hline 1980 to 1990 & 0.035 & 0.087 & $\begin{array}{c}0.053 \\
(0.0230) \\
{[0.026]}\end{array}$ \\
\hline 1990 to 2000 & 0.049 & 0.055 & $\begin{array}{c}0.006 \\
(0.0233) \\
{[0.790]}\end{array}$ \\
\hline
\end{tabular}

Workers with high school degree:

Change in non-participation rates

1970 to 1980

Nonindustrial Cities

0.140

0.023

1990 to 2000

0.020

Nonindustrial Cities

0.104

0.003

0.002

1990 to 2000 rates

1970 to 1980

1980 to 1990

1990 to 2000

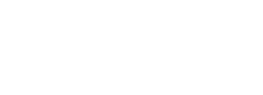

Workers with bachelor's degree or more:

Change in non-participation Nonindustrial Cities rates

1970 to 1980
1990 to 2000

1980 to 1990
0.050

0.007

0.010
Difference

$-0.048$

$(0.0255)$

[0.066]

0.061

(0.0148)

[0.000]

0.020

(0.0151)

[0.187]
Difference

$-0.037$

(0.0387)

[0.350]

0.066

(0.0191)

[0.001]

0.032

(0.0102)

[0.003]

Notes: Authors' calculations, 1970 to 2000 PUMS and BEA's REIS data. For additional notes, see Table 5. 
Figure 1: The Decline in Real Earnings in the US Primary Metals industry, 1969 to 2000

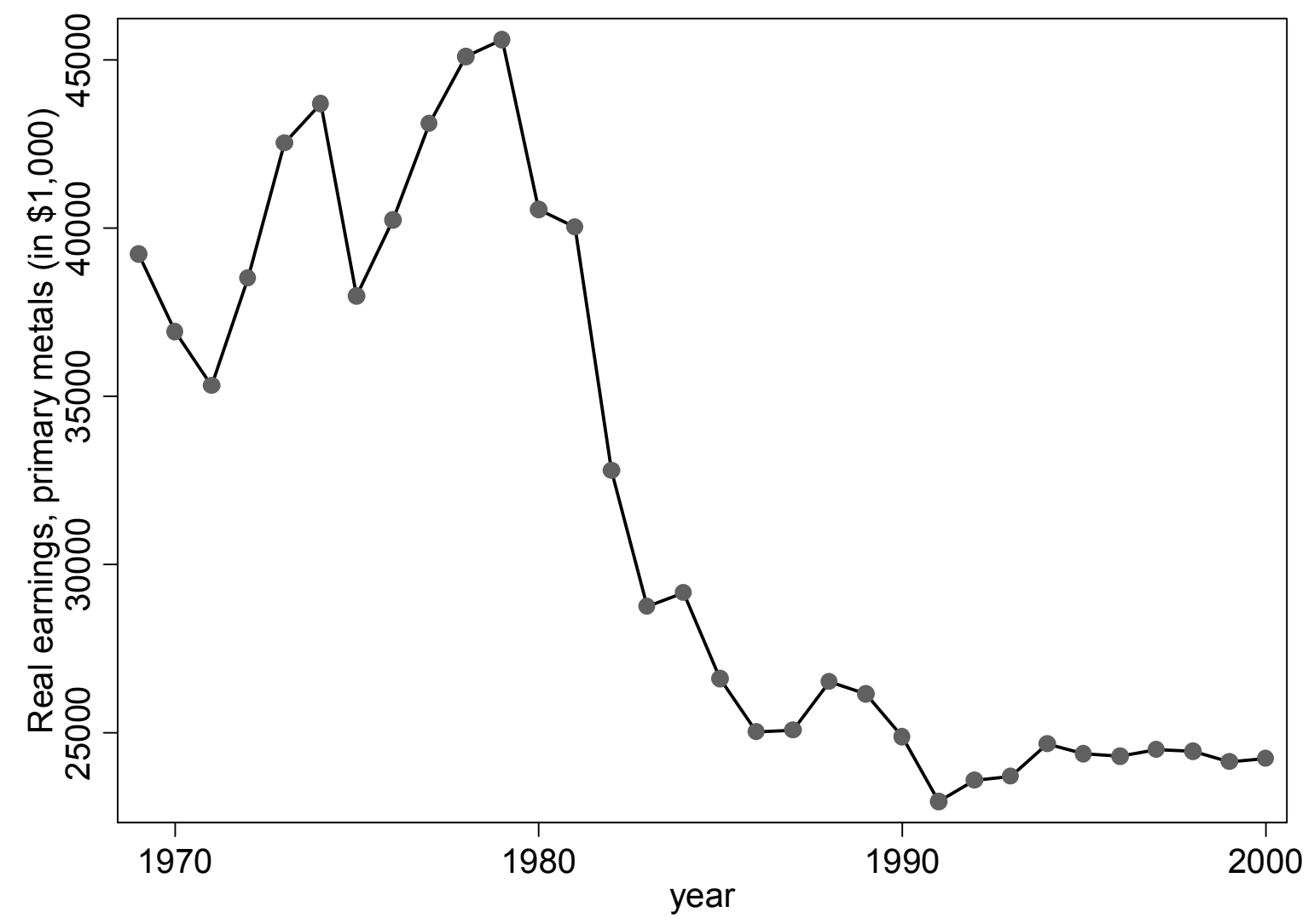

Source: Authors' calculation, BEA's REIS data. 
Figure 2: The Real Price of Coal, 1946-1993, and Mining Employment as a Percent of Total Employment, 1969-1993

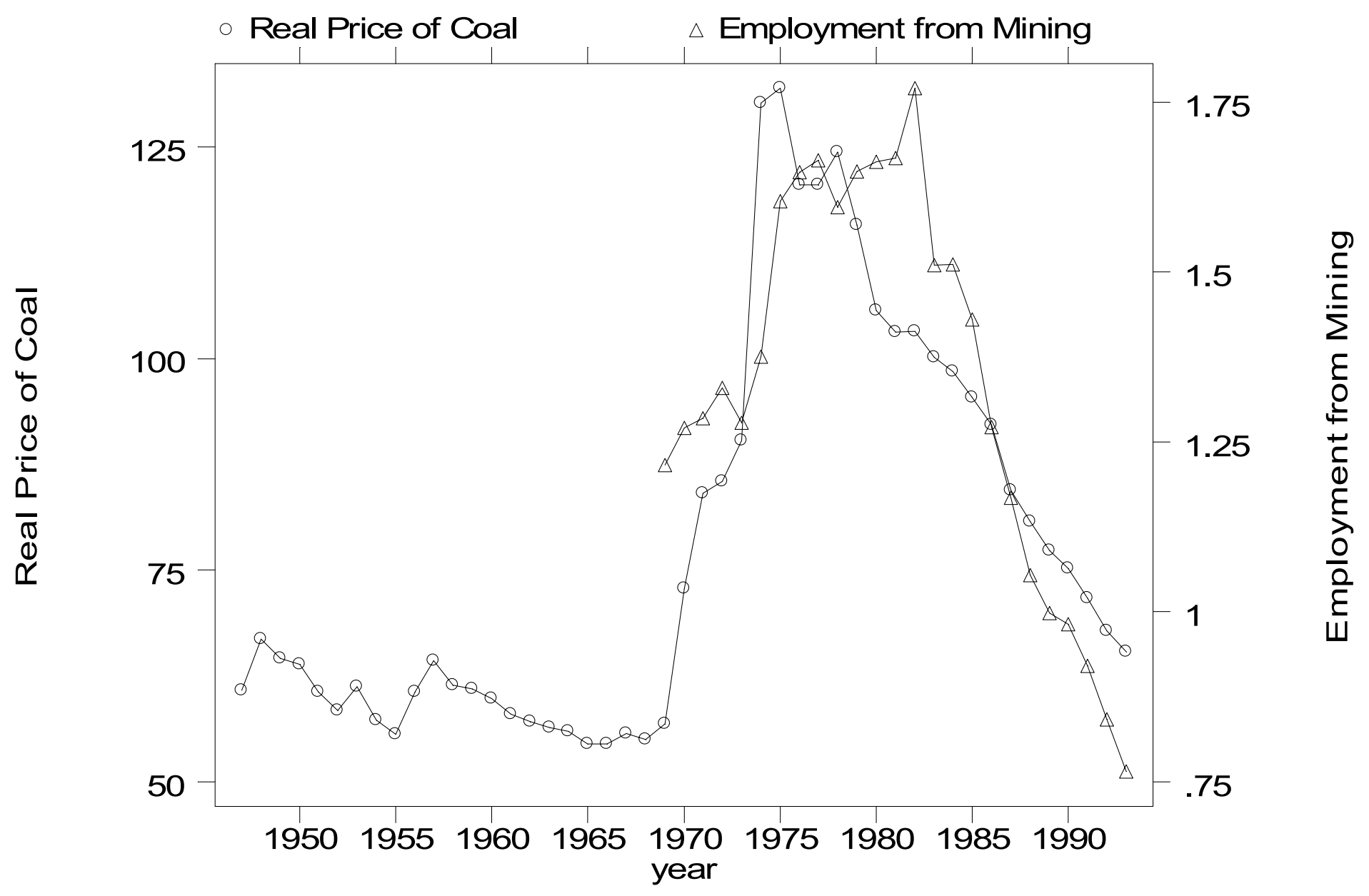


FIGURE 3: Coal Reserves: Kentucky, Ohio, Pennsylvania, and West Virginia

Coal Reserves

Less than 100 million tons

100-999 million tons

1 billion tons or more

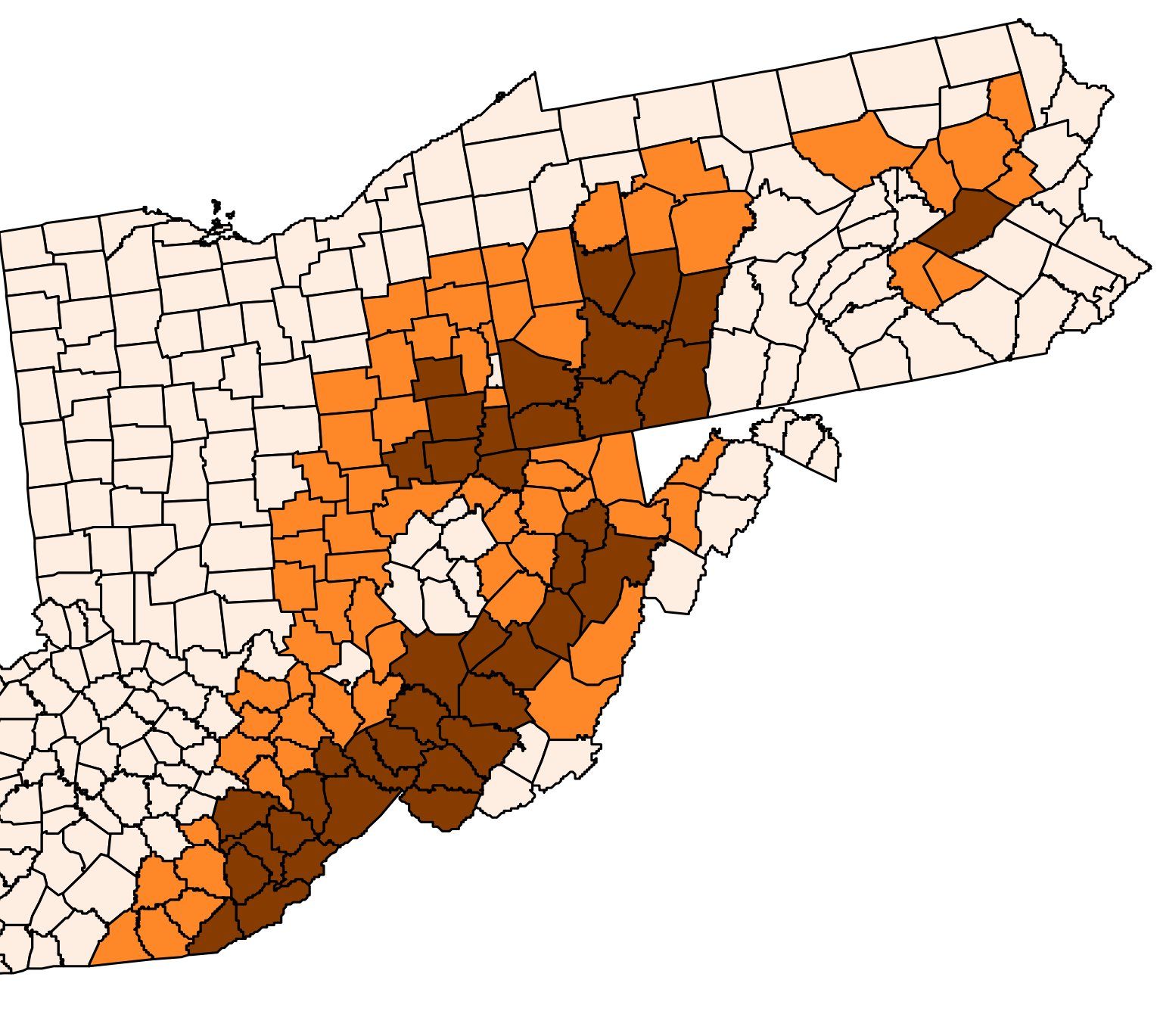


Figure 4: Fraction of Employment in Manufacturing the United States, 1969 to 2000

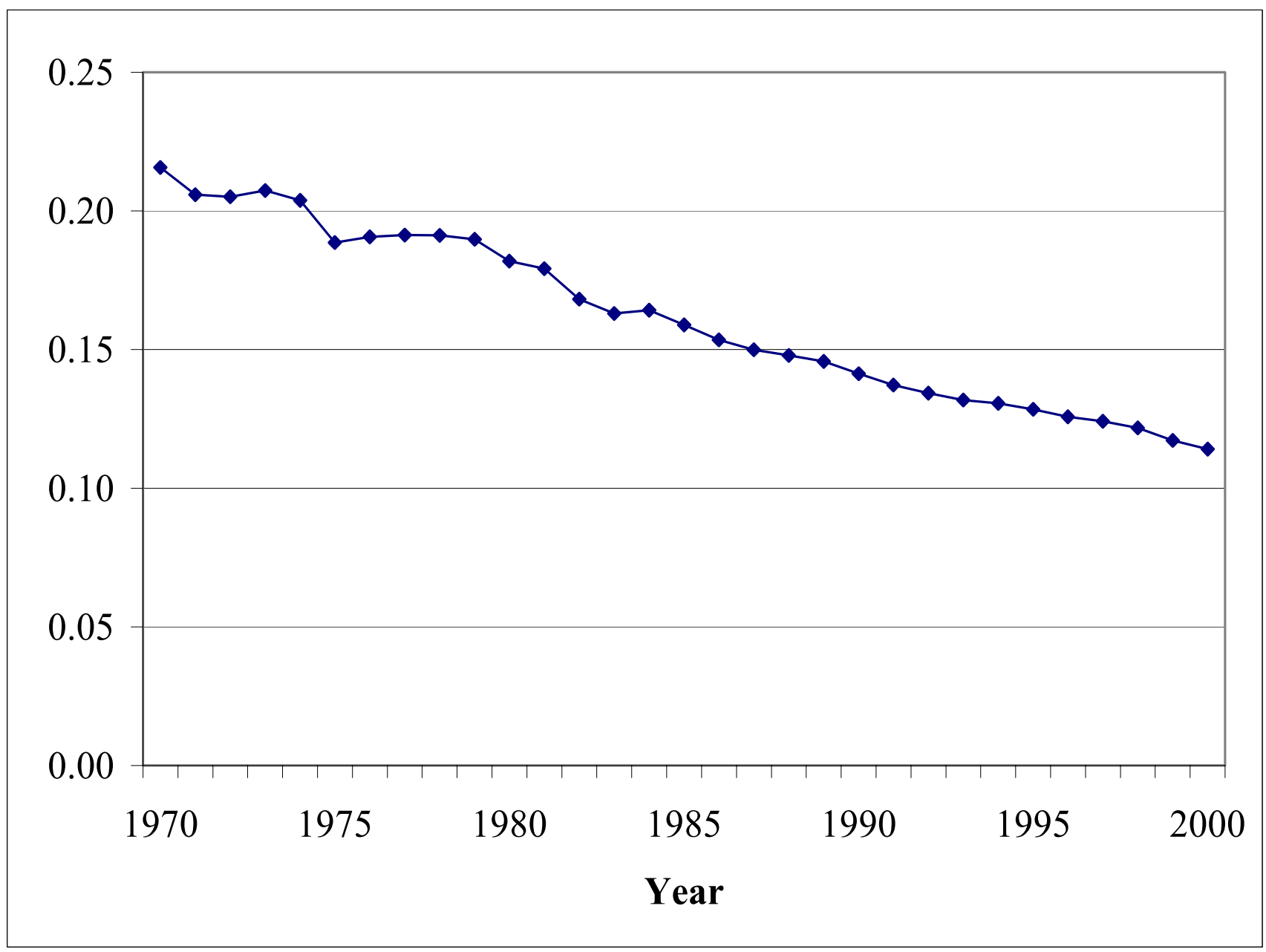

Source: Authors' calculation, BEA’s REIS data. 


\section{References}

Black, D. K. Daniel, and S. Sanders, 2002. "The Impact of Economic Conditions on Disability Program Participation: Evidence from Coal Boom and Bust" American Economic Review March 92(1) 27-50.

Black, D., T. McKinnish, and S. Sanders, 2003. "Does the Availability of High-Wage Jobs for Low-Skilled Men Affect Welfare Expenditures? Evidence from Shocks to the Coal and Steel Industries" Journal of Public Economics September 87(9-10) 1919-40.

Blau, David, 1998. "Labor Force Dynamics of Older Couples" Journal of Labor Economics July (16)3 595-629.

Chan, Sewin and Ann Huff Stevens, 2001. "Job Loss and the Employment Patterns of Older Workers" Journal of Labor Economics 19(2).

Chan, Sewin and Ann Huff Stevens, 2002. "How Does Job Loss Affect the Timing of Retirement?" NBER Working Paper 8780.

Hurd, Michael D., 1997 "The Economics of Individual Aging” in M.R. Rosenzweig and O. Stark's Handbook of Population and Family Economics volume 1B, Amsterdam: Elsevier

Jacobson, Louis S., Robert J. LaLonde and Daniel G. Sullivan, 1993. "Earnings Losses of Displaced Workers" American Economic Review 83(4): 685-709.

King, Miriam, Steven Ruggles, and Matthew Sobek. Integrated Public Use Microdata Series, Current Population Survey: Preliminary Version 0.1. Minneapolis: Minnesota Population Center, University of Minnesota, 2003. www.ipums.org/cps

Lumsdaine, Robin and Olivia Mitchell, 1999. "'New Developments in the Economic Analysis of Retirement" in O. Ashenfelter and D. Card's Handbook of Labor Economics volume 3C, Amsterdam: Elsevier

Theil, Henri, 1971. Principles of Econometrics New York: John Wiley and Sons

U. S. Board of Trustees of the Federal Old-Age and Survivors Insurance and Disability Insurance Trust Fund, 2004. The 2004 Annual Report of the Board of Trustees of the Federal OldAge and Survivors Insurance and Disability Insurance Trust Funds Washington: Government Printing Office

Wald, Abraham, 1940. "The Fitting of Straight Lines if Both Variables are Subject to Error" Annals of Mathematical Statistics 11: 284-300.

Wilson, William J. 1987. The Truly Disadvantaged: The Inner City, the Underclass, and Public Policy. Chicago: University of Chicago Press.

Wilson, William J. 1996. When Work Disappears: The World of the New Urban Poor. New York: Alfred A. Knopf. 
Wilson, William J. and Kathryn M. Neckerman. 1986. "Poverty and Family Structure: The Widening Gap between Evidence and Public Policy Issues.” In Sheldon H. Danziger and Daniel H. Weinberg (eds.), Fighting Poverty: What Works and What Doesn't. Cambridge, MA: Harvard University Press. 


\section{RECENT WORKING PAPERS FROM THE \\ CENTER FOR RETIREMENT RESEARCH AT Boston COLLEGE}

Validation Study of Earnings Data in the SIPP_Do Older Workers Have Larger Measurement Error?

Peter Gottschalk and Minh Huynh, May 2005

Investment Choice in the Swedish Premium Pension Plan

Mårten Palme, Annika Sundén, and Paul Söderlind, April 2005

Design and Implementation Issues in Swedish Individual Pension Accounts

R. Kent Weaver, March 2005

Lashed to the Mast?: The Politics of Notional Defined Contribution Pension Reforms

Sarah M. Brooks and R. Kent Weaver, January 2005

Understanding Expenditure Patterns in Retirement

Barbara A. Butrica, Joshua H. Goldwyn, and Richard W. Johnson, January 2005

Changes in the Distribution of Long-Run Earnings and Retirement Incomes-Have Recent Cohorts Fallen Behind?

Peter Gottschalk and Minh Huynh, January 2005

The Age Profile of Income and the Burden of Unfunded Transfers in Four

Countries: Evidence from the Luxembourg Income Study

Gary Burtless, December 2004

Projecting Immigration: A Survey of the Current State of Practice and Theory Neil Howe and Richard Jackson, December 2004

Nonearnings Income Migration in the United States: Anticipating the Geographical Impacts of Baby Boom Retirement

Peter B. Nelson, December 2004

Does Work Pay at Older Ages?

Barbara A. Butrica, Richard W. Johnson, Karen E. Smith, and Eugene Steuerle, November 2004

All working papers are available on the Center for Retirement Research website

(http://www.bc.edu/crr) and can be requested by e-mail (crr@bc.edu) or phone (617-552-1762). 